\title{
The complete nucleotide sequence of cosmid vector pTL5: location and origin of its genetic components
}

\author{
(Recombinant DNA; pBR322; phage $\lambda$; phage $\phi 80$; bacteriophage cohesive ends; Charon 4A)
}

\author{
Jerry L. Slightom ${ }^{\mathrm{a}, \mathrm{b}}$, David R. Siemieniak ${ }^{\mathrm{b}}$, Ben F. Koop ${ }^{\mathrm{e}}$ and Leroy Hood ${ }^{\mathrm{d}}$ \\ Molecular Biology Unit 7242, The Upjohn Company. Kalanazoo. MI 49007, USA; Human Genome Center, The University of Michigan, Ann Arbor, \\ MI 48109-0650, USA. Tel. (1-313) 747-4783; 'Department of Biology-Center for Environmental Health, University of Victoria, Victoria, BC. V8W $2 Y 2$, \\ Canada. Tel (1-604) 656-8146; and 'Department of Molecular Biotechnology. University of Washington, Seattle, WA 98105, USA. Tel. (1-206) 685-7367
}

Received by D.L. Daniels: 6 March 1994; Accepted: 4 April 1994; Received at publishers: 25 April 1994

\section{SUMMARY}

The complete nucleotide sequence ( $5793 \mathrm{bp}$ ) of the cosmid vector pTL5 and the origin of its genetic components has been determined. Cosmid pTL5, a derivative of cosmid vector pHC79, is composed of genetic components from pBR322, bacteriophage $\lambda$ and the hybrid lambdoid bacteriophage Charon (Ch) $4 \mathrm{~A}$ cohesive ends (cos) region. The Ch4A cos region contains genetic components from two bacteriophages, the $\lambda$ cos-left arm and the $\phi 80$ cos-right arm regions. The Ch4A cos region has been used in the construction of many other cosmid-type vectors, some of which have been sequenced and entered into the GenBank database.

\section{INTRODUCTION}

Cosmid-type cloning vectors are generally composed of an E. coli plasmid origin of replication (in many cases the ColE1 ori), at least one antibiotic resistance gene and a bacteriophage cos region. Hohn and Collins (1980) constructed the versatile cosmid, pHC79; it contains pBR322 (ColE1 ori and the tet and bla genes that encoding $\mathrm{Tc}^{\mathrm{R}}$ and $A p^{R}$, respectively), a $0.65-\mathrm{kb}$ fragment from the $\lambda$ crocII region and the chimeric bacteriophage cos region contained within a 1.74-kb $B g / \mathrm{II}$ fragment isolated from Ch4A. Cosmid vector pTL5 is essentially pHC79 in which

Correspondence to: Dr. J.L. Slightom, Molecular Biology Unit 7242 , The Upjohn Co., Kalamazoo, MI 49007, USA. Tel. (1-616) 385-5304; Fax (1-616) 385-4599; e-mail: jslighto@upj.com

\footnotetext{
Abbreviations: aa, amino acids(s); Ap, ampicillin; bla, gene encoding $\beta$-lactamase; bp, base pair(s); $\mathrm{Ch}$, Charon; $c o s$, cohesive end( $s$ ) of $\lambda$ or $\phi 80$ bacteriophage; E., Escherichia; GCG, Genetics Computer Group (Madison, WI, USA); kb, kilobase(s) or $1000 \mathrm{bp;} \mathrm{nt,} \mathrm{nucleotide(s);} \mathrm{ori,}$ origin of DNA replication; ${ }^{\mathbf{R}}$, resistance/resistant; Tc, tetracycline; tet, gene encoding $\mathrm{Tc}^{\mathrm{R}}$.
}

the bla gene and the BglII site adjacent to the $\lambda \cos$-left arm were removed (Lund et al., 1982).

\section{EXPERIMENTAL AND DISCUSSION}

\section{(a) Genetic components of pTL5}

Knowledge of the $n t$ sequence of cosmid vectors is important to cloning, mapping and nt sequencing projects, especially those that utilize the 'shotgun' method (Koop et al., 1993), because some of the nt sequencing runs will include vector-derived sequences. While sequencing parts of the mouse and human T-cell receptor variable gene clusters (Lai et al., 1988; Koop et al., 1994; Slightom et al., 1994) we also determined the complete double-stranded sequence of the cosmid vector pTL5. The sequence of pTL5 (GenBank accession No. U07340) was determined by the manual primer-walking method using ${ }^{32}$ P-radioisotope labeling (Siemieniak et al., 1991) and the shotgun sequencing method using dye-labeled primers and the ABI 373A instrument (Koop et al., 1993). The identification of pTL5 genetic components is for 
TABLE I

Components of pTL5

\begin{tabular}{|c|c|c|c|c|}
\hline Component & pTL5 location ${ }^{a}$ & $\begin{array}{l}\text { Origin } \\
(\text { Ori })\end{array}$ & $\begin{array}{l}\text { GenBank } \\
\text { No. }\end{array}$ & Reference(s) \\
\hline $\operatorname{Tc}^{\mathrm{R}}(t e t)$ & $1 / 1460(99.93)^{b}$ & $\mathrm{pBR} 322$ & J01749 & Bolivar et al. (1977): Sutcliffe (1978) \\
\hline$\lambda(r)-\mathrm{cII}$ & $1461 / 2113(100)$ & $\lambda$ & $\mathrm{J} 02459 / \mathrm{M} 17233$ & Daniels et al. (1982) \\
\hline cos-right arm & $2114 / 3448(98.5)^{\mathrm{c}}$ & $\phi 80$ & none & D.L. Daniels and F.R. Blattner (unpublished) \\
\hline cos-left arm & $3437 / 3854(99.8)^{\mathrm{d}}$ & 2 & $102459 / \mathrm{M} 17233$ & Daniels et al. (1982) \\
\hline ColE1 ori & $3855 / 5793(100)$ & pBR322 & 101749 & Bolivar et al. (1977); Sutcliffe (1978): Watson (1988) \\
\hline
\end{tabular}

${ }^{a}$ Numbers in parentheses indicate the \% nt identity between the pTL5 nt sequence and the indicated GenBank entry.

${ }^{b}$ Note that GenBank entry No. J01749 differs at position 1134 (C) of tet vs. pTL5 (T), which encodes the aa replacement Thr ${ }^{35 \%} \rightarrow 11$ e. Other Gen Bank entries for tet share the identical nt at position 1134 with the pTL5 sequence; see Ahmed (1989) and GenBank aceessions M20189 and L08817.

c $100 \%$ identity between the $\phi 80$ and pTI.5 sequences is not expected because the sequence of $\phi 80$ is preliminary (D.L. Daniels and F.R. Blattner. personal communication).

${ }^{d}$ These $n t$ sequences differ at $\lambda$ position 138 , where the $\lambda$ sequence contains an extra $G$ that is not found in pTL5.

the most part straightforward (Table I), except for the 1.3 -kb cos-right arm region. The $\mathrm{Ch} 4 \mathrm{~A}$ cos region is composed of the $\phi 80$ cos-right and $\lambda$ cos-left arm regions (Williams and Blattner, 1979). Interestingly, there are only limited nt sequence homologies between bacteriophage $\lambda$ and $\phi 80$ (Fiandt et al., 1971). This was confirmed by comparing the pTL5 nt sequences (positions 2114 to 3448 ) and $\lambda$ right arm nt sequences (Sanger et al., 1982; Daniels et al., 1982) which reveals only a small region of nt identity $(63$ bp that share $89 \%$ identity which includes the identical 12-bp cos sequence). Confirmation that the pTL5 cos-right arm was derived from $\phi 80$ was obtained by comparing this $n t$ sequence with that from the $\phi 80$ cos-right arm (Table 1). These sequences share 98.5\% identity over the compared $1.3 \mathrm{~kb}$, the small degree of non-identity being compatible ambiguities in the preliminary sequence of the $\phi 80$ cos-right arm.

\section{(b) Structure and sequence of pTL5-related cosmids}

Many other cosmid vectors use all or part of the chimeric Ch4A cos region and some of these have been completely sequenced and entered into GenBank, as revealed by a GenBank search (release 80 , using the GCG FASTA

TABLE II

Sequenced cosmid vectors that contain the $\phi 80$ cos-right arm genetic component

\begin{tabular}{lll}
\hline Name & p80 identity region & $\begin{array}{l}\text { GenBank } \\
\text { No. }\end{array}$ \\
\hline pIB8/pHomerl & $3284.4620(100)$ & U 00003 \\
pTCF & $7657-6321(100)$ & L 19899 \\
svPHEP & $5962-7298(100)$ & L 19900 \\
pWE15 & $5986-7322(100)$ & X65279/M99569 \\
pWE15A & $6026-6362(100)$ & Z12112 \\
sCOS-1 & $1147-299(97.9)$ & M99566 \\
\hline
\end{tabular}

${ }^{a}$ Numbers in parentheses indicate the \% nt identity between GenBank entry sequences and the $\phi 80$ cos-right arm sequence of pTL5. computer program). Table II lists these pTL5-related cosmid vectors. Cosmid pHC79 was not included in the FASTA results, because it is a computer assembled sequence, rather than experimentally determined sequence, in which the $\lambda$ cos-right arm sequence was used in its assembly, see GenBank accession No. VB0100.

\section{ACKNOWLEDGEMENTS}

We are grateful to Donna Daniels and Frederick Blattner, Department of Genetics, University of Wisconsin (Madison, WI, USA), for sharing their preliminary sequence of the $\phi 80$ cos-right arm. We appreciate Earl Adams' (The Upjohn Company) help in proofing some sequence regions of pTL5 using the ABI PRISM ${ }^{\mathrm{TM}}$ kit and $373 \mathrm{~A}$ fluorescence sequencer. We also thank Roger Drong (The Upjohn Company) for helpful comments and critical reading of this manuscript.

\section{REFERENCES}

Ahmed, A.: A vector for sequencing long (40-kb) DNA fragments. Gene 75 (1989) 315-321.

Bolivar, F., Rodriguez, R.L. Greene, P.J., Betlach, M.C., Heyneker, H.L., Boyer, H.W., Crosa, J.H. and Falkow, S.: Construction and characterization of new cloning vehicles. II. A multipurpose cloning system. Genc 2 (1977) 95-113.

Daniels, D.L., Schroeder, J.L., Szybalski, W., Sanger, F.. Coulson, A.R., Hong, G.-F., Hill, D.F., Peterson, G.B. and Blattner, F.R.: Complete annotated lambda sequence. In: Hendrix. R.W.. Roberts. J.W.. Stahl, F.W. and Weisberg. R.A. (Eds.), Lambda II. Cold Spring Harbor Laboratory, Cold Spring Harbor, NY, 1983, pp. 519-676.

Fiandt, M., Hradecna, Z., Lozeron, H.A. and Szybalski. W.: Electron micrographic mapping of deletions. insertions, inversions, and homologies in the DNAs of coliphages lambda and phi80. In: Hershey, A.D. (Ed.), The Bacteriophage Lambda, Cold Spring Harbor Laboratories, Cold Spring Harbor, NY, 1971, pp. 329-354. 
Hohn, B. and Collins, J.: A small cosmid for efficient cloning of large DNA fragments. Gene 11 (1980) 291-298.

Koop, B.F., Rowen, L., Chen, W.-Q., Deshpande, P., Lee, H. and Hood, L.: Sequence length and error analysis of sequences and automated Taq cycle sequencing methods. BioTechniques 14 (1993) 442-447.

Koop, B.F., Rowen, L., Wang, K., Kuo, C.L., Seto, D., Lenstra, J.A., Howard, S., Shan, W., Deshpande, P. and Hood, L.: The human T-cell receptor TCRAC/TCRDC $\mathrm{C} \alpha / \mathrm{C} \delta$ region: organization, sequence, and evolution of $97.6 \mathrm{~kb}$ of DNA. Genomics 19 (1994) 478-493.

Lai, E., Concannon, P. and Hood, L.: Conserved organization of the human and murine T-cell receptor $\beta$-gene families. Nature 331 (1988) 543-546.

Lund, T., Grosveld, F.G. and Flavell, R.A.: Isolation of transforming DNA by cosmid rescue. Proc. Natl. Acad. Sci. USA 79 (1982) $520-524$.

Sanger, F., Coulson, A.R., Hong, G.F., Hill, D.G. and Petersen, G.B.:
Nucleotide sequence of bacteriophage $\lambda$ DNA. J. Mol. Biol. 162 (1982) 729-773.

Siemieniak, D.R., Sieu, L.C. and Slightom, J.L.: Strategy and methods for directly sequencing cosmid clones. Anal. Biochem. 192 (1991) $441-448$.

Slightom, J.L., Siemieniak, D.R., Sieu, L.C., Koop, B.F. and Hood, L.: Nucleotide sequence analysis of $77.7 \mathrm{~kb}$ of the human $\mathrm{V}_{\beta} \mathrm{T}$-cell receptor gene locus. Genomics 20 (1994) 149-168.

Sutcliffe, IG.: Complete nucleotide sequence of the Escherichia coli plasmid pBR322. Cold Spring Harbor Symp. Quant. Biol. 43 (1978) 77-90.

Watson, N.: A new revision of the sequence of plasmid pBR322. Gene 70 (1988) 399-403.

Williams, F.B. and Blattner, F.R.: Construction and characterization of the hybrid bacteriophage lambda Charon vectors for DNA cloning. J. Virol. (1979) 555-575. 